\title{
Effect of secondary hyperparathyroidism serum on endothelial cells and intervention with Klotho
}

\author{
CHENG CHEN $^{1,2}$, HUIJUAN MAO ${ }^{1}$, XIANGBO YU ${ }^{1}$, BIN SUN ${ }^{1}$, MING ZENG ${ }^{1}$, \\ XIUFEN ZHAO $^{1}$, JUN QIAN ${ }^{1}$, JIA LIU ${ }^{1}$ and CHANGYING XING ${ }^{1}$ \\ ${ }^{1}$ Department of Nephrology, The First Affiliated Hospital of Nanjing Medical University, Nanjing, Jiangsu 210029; \\ ${ }^{2}$ Department of Nephrology, Yangzhou No. 1 People's Hospital, Yangzhou, Jiangsu 225000, P.R. China
}

Received May 14, 2014; Accepted March 9, 2015

DOI: $10.3892 / \mathrm{mmr} .2015 .3606$

\begin{abstract}
The aim of the present study was to investigate the effect of the serum of patients with secondary hyperparathyroidism (SHPT) on endothelial cells and to examine the protective effect and the possible mechanism of Klotho. A total of three types of mixed serum from 15 patients with SHPT scheduled for parathyroidectomy, 10 chronic kidney disease (CKD) patients at stage 5 without SHPT and 15 healthy volunteers were collected. Initially, human umbilical vein endothelial cells (HUVECs) were incubated in vitro with the three types of serum and levels of proliferation were compared by assessing viable cell numbers with cell counting kit- 8 (CCK-8). Subsequently, HUVECs were divided into three groups: Control group (healthy serum medium), SHPT group (SHPT serum) and Klotho treatment group (SHPT serum and Klotho). The proliferative and apoptotic levels of endothelial cells were evaluated by CCK- 8 and flow cytometry, respectively. The levels of extracellular signal-regulated kinase (ERK1/2) and phosphorylated forms of ERK1/2 (p-ERK1/2) were detected using western blotting (with or without ERK1/2 inhibitor PD98059). The synthesis of nitric oxide (NO) was measured using the nitrate reduction method. The proliferation of HUVECs was inhibited by the serum from SHPT patients and CKD-5 patients without SHPT and the inhibitory effects of the SHPT serum were the most marked $(\mathrm{P}<0.05)$. Inhibition of HUVEC proliferation by SHPT serum occurred in a concentration-dependent manner within a specific range $(5-20 \% ; \mathrm{P}<0.05)$ and also in a time-dependent manner within 6-24 h. Proliferation was partly restored and apoptosis was inhibited when $50-100 \mathrm{ng} / \mathrm{ml}$ Klotho was added into $10 \%$ SHPT serum $(\mathrm{P}<0.05)$. At the same time, the expression of $\mathrm{p}-\mathrm{ERK} 1 / 2$
\end{abstract}

Correspondence to: Mrs. Huijuan Mao, Department of Nephrology, The First Affiliated Hospital of Nanjing Medical University, 300 Guangzhou Road, Nanjing, Jiangsu 210029, P.R. China E-mail: huijuanmao@126.com

Key words: Klotho protein, secondary hyperparathyroidism, human umbilical vein endothelial cells, apoptosis, extracellular signal-regulated kinase, nitric oxide was upregulated, which may be inhibited by PD98059. The synthesis of NO was decreased in the SHPT group $(\mathrm{P}<0.05)$ and increased following treatment with Klotho $(\mathrm{P}<0.05)$. The results of the present study indicated that the proliferation of HUVECs was inhibited by the serum from SHPT patients. Klotho may partly antagonize this effect due to its inhibition of HUVEC apoptosis and upregulation of p-ERK1/2.

\section{Introduction}

Cardiovascular disease (CVD) is an important prognostic factor in patients with chronic kidney disease (CKD). Mortality due to CVD in patients with CKD accounted for 44-51\% of the total mortality, which is the leading cause of mortality in these patients. Levels of mortality in dialysis patients with CVD was 30 times higher than that of the general population at the same age (1) and atherosclerosis was the most common cardiovascular complication. Endothelial cells are responsible for lining the inner surface of the entire vascular system; they are involved in the maintenance of normal blood flow and are the basis of the closed conduits, which form the cardiovascular system. Dysfunction of the endothelium has an important role in the incidence of atherosclerosis. A large number of uremic toxins accumulating in uremic patients lead to vascular endothelial cell dysfunction (2) and accelerate the development of CVD. The concentration of parathyroid hormone (PTH) in uremia patients with secondary hyperparathyroidism (SHPT) is several times higher than that in non-SHPT uremic patients. High PTH levels may increase blood pressure, exacerbating the development of hyperlipidemia and are also an important factor for the development of atherosclerosis in patients with end-stage renal disease (3). A meta-analysis recently indicated that high concentrations of PTH were closely associated with an increased risk of suffering a cardiovascular event (4).

In 1997, Kuro-o et al (4) identified a novel gene associated with aging, termed Klotho. Klotho gene knockout mice (kl-/-mice) present with a variety of similar phenotypes to that observed in aging humans, including shortened life expectancy, hearing loss, infertility, atherosclerosis, soft tissue calcification, skin atrophy, osteoporosis and emphysema (5-8). Klotho is highly expressed in the normal kidney. With a decline in the glomerular filtration rate, Klotho gene and protein expression levels significantly decrease in CKD patients (9). Previous 
studies have demonstrated that Klotho protein has a protective effect on endothelial cell damage and dysfunction induced by angiotensin-II and tumor necrosis factor $\alpha(10,11)$, as well as the uremic toxin indoxyl (12). It is hypothesized that reduced Klotho in the peripheral organs is closely associated with the complications of uremia and increased Klotho levels may improve the complications of uremia. In the present study, by simulating the state of SHPT in vivo, the proliferation, apoptosis and nitric oxide (NO) synthesis of human umbilical vein endothelial cells (HUVECs) in the serum from patients with SHPT was investigated and the effect of recombinant Klotho protein on HUVECs and the possible mechanism of this effect was examined.

\section{Materials and methods}

Materials. HUVECs were kindly provided by the Central Laboratory of the First Affiliated Hospital of Nanjing Medical University (Nanjing, China). HUVECs were purchased from ATCC (Manassa, VA ,USA; cat. no. PCS-100-010) RPMI-1640 medium, fetal bovine serum, penicillin and streptomycin were purchased from Gibco-BRL (Grand Island, NY, USA). The cell counting kit- 8 (CCK-8) detection kit (Beyotime, Shanghai, China) was used to assess cell viability. PD98059 (ERK1/2 inhibitor), total ERK1/2 (t-ERK1/2) mouse antibody (cat. no. 9107S) and phosphorated ERK1/2 (p-ERK1/2) antibody (cat. no. 9106S) were purchased from Cell Signaling Technology, Inc, (Danvers, MA, USA). A rabbit anti-GAPDH antibody (cat. no. BA2913; Wuhan Boster Biological Technology, Ltd., Wuhan, China) was used for western blotting analysis. SDS PAGE gels were purchased from Beyotime Institute of Biotechnology (Shanghai, China). Recombinant Klotho protein was purchased from PeproTech (cat. no. 100-53; Rocky Hill, NJ, USA). The annexin V-fluorescein isothiocyanate apoptosis detection kit (KeyGEN, Nanjing, China) was used to assess the levels of cell apoptosis using flow cytometry. A human Klotho ELISA kit was purchased from USCN Life Science Inc. (Wuhan, China). An NO detection kit (Nanjing Jiancheng Bioengineering Institute, Nanjing, China) was used to assess the production of NO in the supernatants.

A total of three types of mixed serum were collected, inactivated and preserved at $-80^{\circ} \mathrm{C}$. The first type was from 15 patients with SHPT scheduled for parathyroidectomy, 8 males and 7 females, aged 28-59 (45.3 \pm 9.7$)$. This sera was collected between July $1^{\text {st }}$ and October $30^{\text {th }} 2012$ from patients without infection. Every patient iPTH was $>800 \mathrm{pg} / \mathrm{ml}$. The second was from 10 CKD-stage 5 without SHPT patients:

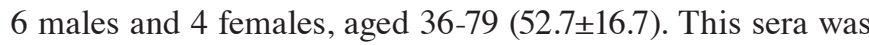
collected from patients between July $1^{\text {st }}$ and October $30^{\text {th }} 2012$ from patients whose eGFR was $<15 \mathrm{ml} / \mathrm{min}$, without infection. Every patient iPTH was $<300 \mathrm{pg} / \mathrm{ml}$. The third was from 15 healthy volunteers, 12 males and 3 females, aged 24-71 (41.4 \pm 19.5$)$. The present study was approved by the ethics committee of Nanjing Medical University, Nanjing, China.

Cell culture. Cells were routinely cultured in RPMI-1640 medium supplemented with $10 \%$ fetal bovine serum, $100 \mathrm{U} / \mathrm{ml}$ penicillin and $100 \mathrm{U} / \mathrm{ml}$ streptomycin at $37^{\circ} \mathrm{C}$ in a humidified atmosphere with $5 \% \mathrm{CO}_{2}$. All experiments were conducted using cells at passage 5-10.
Assessment of the main constituents of the three types of mixed serum. The three groups of sera were analyzed using an automatic chemistry analyzer analyzer (AU5400; Beckman Coulter, Fullerton, CA, USA) to detect blood urea nitrogen (BUN), creatinine $(\mathrm{Cr})$, uric acid (UA), calcium $(\mathrm{Ca})$ and phosphate $(\mathrm{P})$ in the clinical testing center of The First Affiliated Hospital of Nanjing Medical University. Intact parathyroid hormone (iPTH) and C-reactive protein (CRP) were evaluated by chemiluminescence apparatus (DXI800; Beckman Coulter) and an immunoturbidimetric automatic protein analyzer (BNII; Simens, Inc., Munich, Germany), respectively. The levels of Klotho in the three types of mixed serum were quantified using the human Klotho ELISA kit, according to the manufacturer's instructions.

Cell viability assay. The viability of cells was measured using the CCK- 8 assay. HUVECs were cultured at a density of $10^{4}$ cells/well in a 96-well plate for $24 \mathrm{~h}$ and then incubated in vitro with $10 \%$ SHPT serum or $10 \%$ serum of stage 5 CKD patients without SHPT or serum from healthy individuals $(10 \%)$ as the control. HUVECs were incubated with various concentrations of SHPT sera $(5,10$ or $20 \%)$ for $24 \mathrm{~h}$ and incubated with $10 \%$ SHPT sera for 6,12 and $24 \mathrm{~h}$. To observe different concentrations of Klotho with or without PD98059 on the proliferation of HUVECs, cells were cultured with serum from healthy individuals (10\%) as the control (C), 10\% SHPT serum (S), 10\% SHPT serum with different concentrations of Klotho $(25,50$ or $100 \mathrm{ng} / \mathrm{ml}$; K) and 10\% SHPT serum with different concentrations of Klotho and PD98059 (P) for $24 \mathrm{~h}$. All experiments were repeated at least three times.

Apoptosis assay. To determine whether SHPT serum induced cell apoptosis of HUVECs and the protective role of Klotho, HUVECs were cultured with $10 \%$ SHPT serum, 10\% SHPT serum + Klotho (50 or $100 \mathrm{ng} / \mathrm{ml}), 10 \%$ SHPT serum + Klotho $(50$ or $100 \mathrm{ng} / \mathrm{ml})+$ PD98059 $(10 \mu \mathrm{mol} / \mathrm{l})$ and serum from healthy individuals $(10 \%)$ as the control. Following incubation for $24 \mathrm{~h}$, cells were harvested using $0.25 \%$ trypsin (without ethylene diamine tetraacetic acid) and washed twice with cold phosphate-buffered saline (PBS). Following staining with Annexin V/propidium iodide, the quantitative analysis of cell apoptosis was determined using flow cytometry (FACSCalibur; BD Biosciences, San Jose, CA, USA). All experiments were repeated at least three times.

Immunoblotting. HUVECs were grouped as in the apoptosis assay experiment section. Following incubation for $24 \mathrm{~h}$, the cells were washed with cold PBS. Protein from the cells was homogenized in lysis buffer and was quantified. The protein $(50 \mu \mathrm{g})$ for each sample was separated using SDS-PAGE and the gel (percentage of spacer gel and separation gel was $8 \%$ and $10 \%$, respectively) was transferred onto nitrocellulose membranes. The membranes were blocked with $5 \%$ nonfat dry milk for $2 \mathrm{~h}$ and then incubated overnight at $4^{\circ} \mathrm{C}$ with the corresponding primary antibodies, p-ERK1/2 $(1: 1,000)$ or t-ERK1/2 $(1: 1,000)$. Subsequently, secondary antibodies were applied $(1: 5,000)$ and the signals developed with an ECL plus western blotting detection system (Bio-Rad Laboratories, Inc., Hercules, CA, USA). Densitometric analysis was performed with Image J software version 1.41 (National Institutes of Health, Bethesda, MD, USA). All experiments were repeated at least three times. 
Table I. Main constituents of the mixed serum from patients with secondary hyperparathyroidism, chronic kidney disease at stage 5 without hyperparathyroidism and healthy volunteers.

\begin{tabular}{lccccrr}
\hline Patients & $\begin{array}{c}\mathrm{BUN} \\
(\mathrm{mmol} / \mathrm{l})\end{array}$ & $\begin{array}{c}\mathrm{Cr} \\
(\mu \mathrm{mol} / \mathrm{l})\end{array}$ & $\begin{array}{c}\mathrm{UA} \\
(\mu \mathrm{mol} / \mathrm{l})\end{array}$ & $\begin{array}{c}\mathrm{Ca} \\
(\mathrm{mmol} / \mathrm{l})\end{array}$ & $\begin{array}{c}\mathrm{P} \\
(\mathrm{mmol} / \mathrm{l})\end{array}$ & $\begin{array}{r}\mathrm{iPTH} \\
(\mathrm{pg} / \mathrm{ml})\end{array}$ \\
\hline Healthy volunteers & 3.18 & 43.8 & 305.9 & 2.08 & 1.24 & 13.5 \\
SHPT & 17.57 & 800.0 & 372.9 & 2.49 & 1.81 & 1435.0 \\
CKD-5 without SHPT & 20.55 & 904.0 & 421.8 & 2.38 & 9.77 \\
\hline
\end{tabular}

CKD, chronic kidney disease; SHPT, secondary hyperparathyroidism; BUN, blood urea nitrogen; Cr, creatinine; UA, uric acid; Ca, calcium; $\mathrm{P}$, phosphorus; iPTH, intact parathyroid hormone; CRP, C-reactive protein.

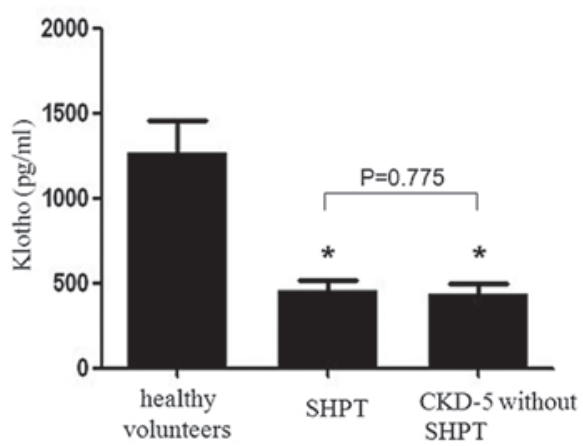

Figure 1. Comparison of Klotho levels in the mixed serum from patients with SHPT, CKD at stage 5 without SHPT and healthy volunteers. ${ }^{*} \mathrm{P}<0.001$ vs. healthy volunteers group. The experiments were repeated three times. SHPT, secondary hyperparathyroidism; CKD, chronic kidney disease.

Measurement of NO production. HUVECs were incubated in vitro with serum from healthy individuals (10\%) as a control, $10 \%$ SHPT serum or $10 \%$ SHPT serum with Klotho (50 or $100 \mathrm{ng} / \mathrm{ml}$ ) for $24 \mathrm{~h}$. The supernatants were collected and the synthesis of NO was measured using the nitrate reduction method, according to the manufacturer's instructions. All experiments were repeated at least three times.

Statistical analysis. Statistical analyses were performed using SPSS 13.0 (SPSS, Inc., Chicago, IL, USA). Values are expressed as the mean \pm standard deviation. Multiple comparisons were evaluated using one-way analysis of variance and significant differences between two groups were analyzed using the Student-Newman-Keuls test. $\mathrm{P}<0.05$ was considered to indicate a statistically significant difference.

\section{Results}

Main constituents of the three types of mixed serum. The main constituents of the mixed serum from patients with SHPT, CKD at stage 5 without SHPT and healthy volunteers are shown in Table I. The levels of BUN, Cr, UA, Ca and P of the mixed serum from patients with SHPT were significantly higher than those from healthy volunteers and the iPTH from patients with SHPT was higher than that from patients with CKD at stage 5 without SHPT. The levels of Klotho in the mixed serum from healthy volunteers, patients with SHPT and CKD at stage 5 without SHPT were $1,264.1 \pm 192.3 \mathrm{pg} / \mathrm{ml}$,
A

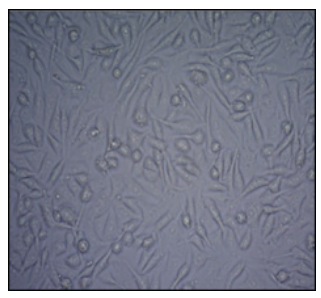

C

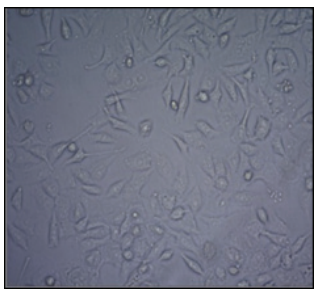

$\mathbf{E}$

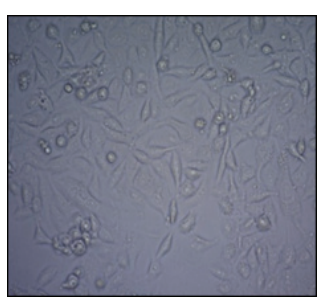

B

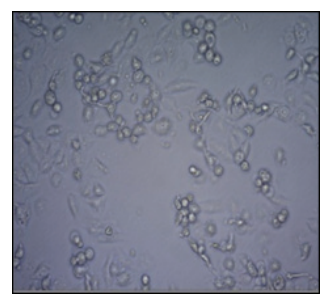

D

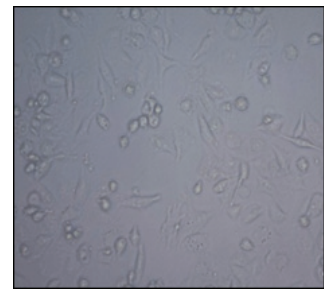

$\mathbf{F}$

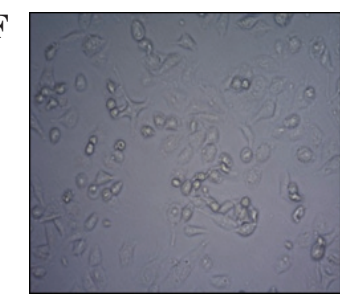

Figure 2. Morphology of human umbilical vein endothelial cells incubated with the $10 \%$ serum from SHPT patients or healthy volunteers for $24 \mathrm{~h}$ with or without Klotho and PD98059 (magnification, x200). (A) 10\% healthy volunteers serum group; (B) $10 \%$ SHPT group; (C) $50 \mathrm{ng} / \mathrm{ml}$ Klotho $+10 \%$ SHPT serum group; (D) $50 \mathrm{ng} / \mathrm{ml}$ Klotho + 10\% SHPT serum + PD 98059 (ERK1/2 inhibitor) group; (E) $100 \mathrm{ng} / \mathrm{ml} \mathrm{Klotho}+10 \%$ SHPT serum group; (F) $100 \mathrm{ng} / \mathrm{ml} \mathrm{Klotho} \mathrm{+} \mathrm{10 \%} \mathrm{SHPT} \mathrm{serum+PD98059} \mathrm{group.} \mathrm{SHPT,}$ secondary hyperparathyroidism.

$458.5 \pm 57.3 \mathrm{pg} / \mathrm{ml}$ and $438.4 \pm 55.2 \mathrm{pg} / \mathrm{ml}$, respectively (Fig. 1). A statistically significant difference was observed between the healthy group and the latter two groups $(\mathrm{P}<0.001)$. However, no statistically significant difference was observed between the SHPT group and the CKD group $(\mathrm{P}=0.775)$.

Morphology of HUVECs. The HUVEC monolayer exhibited a characteristic cobblestone-like appearance in the control group (Fig. 2A). In the SHPT serum group, the number of HUVECs decreased with cell shrinkage and nuclear and cy toplasmic condensation (Fig. 2B). Compared with the SHPT group, the number of the HUVECs in the SHPT+Klotho (50 or $100 \mathrm{ng} / \mathrm{ml}$ ) group increased with the morphology of the cells similar to that of the control (Fig. 2C and E). However, when PD98059 was added to the SHPT + Klotho group, the 


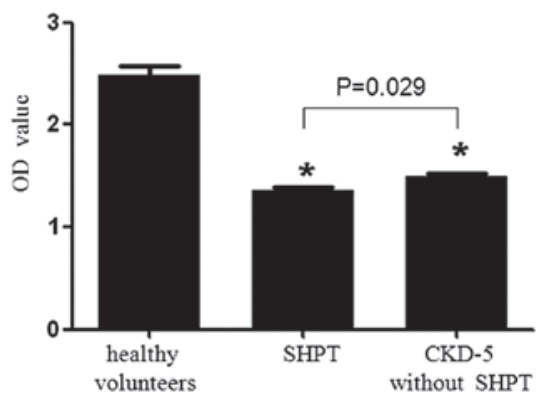

Figure 3. Proliferation of human umbilical vein endothelial cells following incubation with $10 \%$ serum from SHPT patients, CKD patients at stage 5 without SHPT and healthy controls for $24 \mathrm{~h} .{ }^{*} \mathrm{P}<0.001$, vs. healthy control group. The experiments were repeated three times. SHPT, secondary hyperparathyroidism; OD, optical density; CKD, chronic kidney disease.

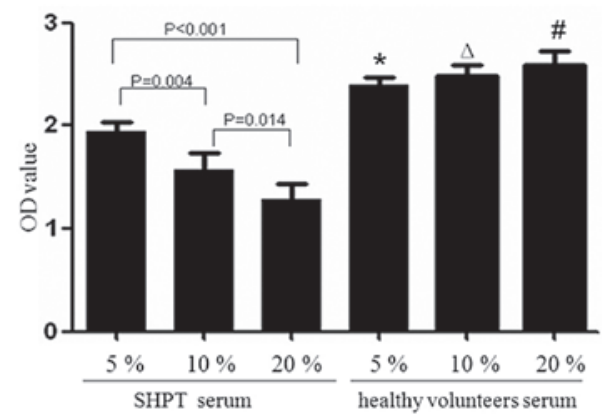

Figure 4. Effect of different concentrations of SHPT serum on the proliferation of human umbilical vein endothelial cells. Statistical differences are expressed as ${ }^{*} \mathrm{P}=0.001$, vs. $5 \%$ SHPT group; ${ }^{\circ} \mathrm{P}<0.001$, vs. $10 \%$ SHPT group; ${ }^{\#} \mathrm{P}<0.001$, vs. $20 \%$ SHPT group. The experiments were repeated three times. SHPT, secondary hyperparathyroidism; OD, optical density.

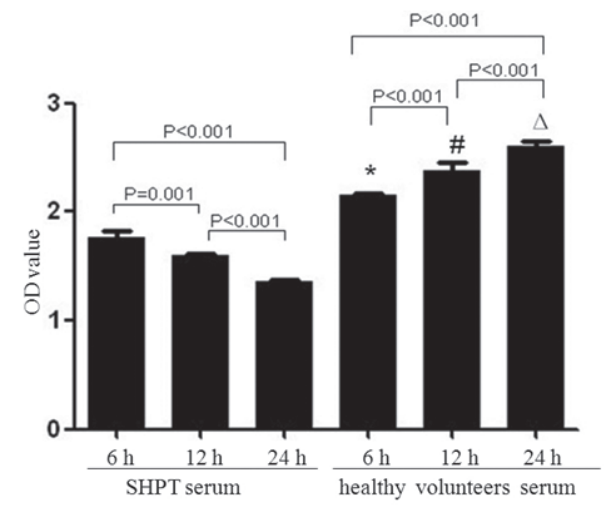

Figure 5. Effect of $10 \%$ SHPT serum on human umbilical vein endothelial cell proliferation following 6,12 or $24 \mathrm{~h}$. "P<0.001, vs. 6 h SHPT group; ${ }^{\text {"P }} \mathrm{P}<0.001$, vs. $12 \mathrm{~h}$ SHPT group; ${ }^{\wedge} \mathrm{P}<0.001$, vs. $24 \mathrm{~h}$ SHPT group. The experiments were repeated three times. SHPT, secondary hyperparathyroidism; OD, optical density.

number of HUVECs decreased and the cells shrank (Fig. 2D and F).

Cell viability and proliferation of HUVECs incubated with the serum from SHPT or CKD patients at stage 5 is decreased. Compared with the healthy control group [optical density $(O D)=2.478 \pm 0.094]$, the proliferation of HUVECs in the

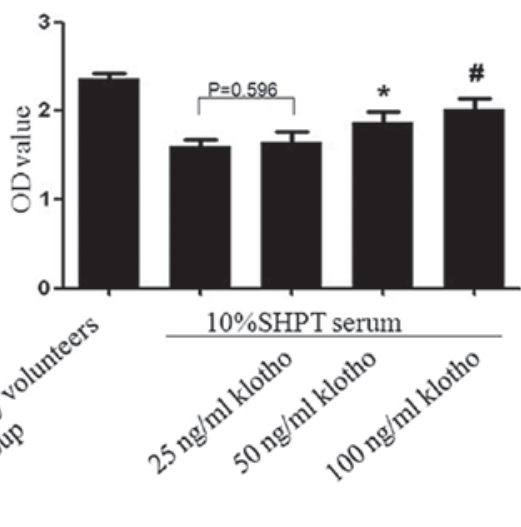

Figure 6. Intervention of different concentrations of Klotho in the proliferation of human umbilical vein endothelial cells incubated with $10 \%$ SHPT serum for 24 h. ${ }^{*} \mathrm{P}=0.01$, vs. $10 \%$ SHPT group; ${ }^{\# P}<0.001$, vs. $10 \%$ SHPT group. The experiments were repeated three times. SHPT, secondary hyperparathyroidism; OD, optical density.

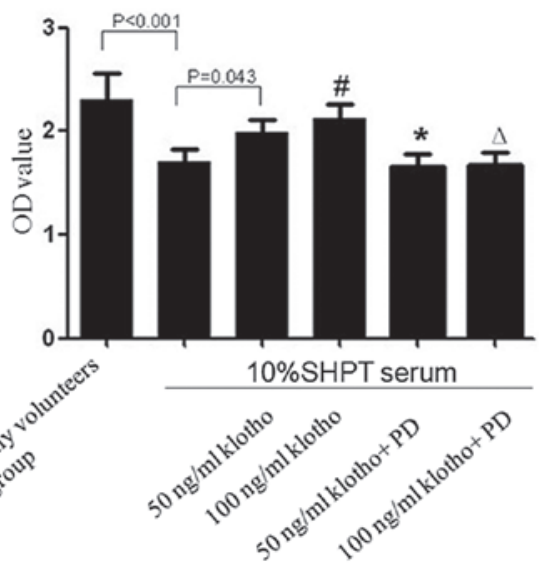

Figure 7. Intervention of different concentrations of Klotho with or without PD98059 (ERK1/2 inhibitor) on the proliferation of human umbilical vein endothelial cells incubated with $10 \%$ SHPT serum for $24 \mathrm{~h} .{ }^{*} \mathrm{P}=0.007$, vs. $10 \%$ SHPT group; ${ }^{*} \mathrm{P}=0.021$, vs. $10 \%$ SHPT $+50 \mathrm{ng} / \mathrm{ml}$ Klotho group; ${ }^{\Delta} \mathrm{P}=0.005$, vs. $10 \% \mathrm{SHPT}+100 \mathrm{ng} / \mathrm{ml}$ Klotho group. The experiments were repeated three times. SHPT, secondary hyperparathyroidism; OD, optical density.

CKD at stage 5 without SHPT group (OD=1.498 \pm 0.027$)$ and SHPT group $(\mathrm{OD}=1.363 \pm 0.023)$ decreased significantly compared with that of the control $(\mathrm{P}<0.001$; Fig. 3$)$. Furthermore, the inhibition of SHPT serum on the proliferation of HUVECs was greater than that of the CKD at stage 5 without SHPT serum $(\mathrm{P}=0.029)$.

SHPT serum inhibits the proliferation of HUVECs in a concentration-dependent manner. Compared with the healthy control group (5, 10 and $20 \%$ ), with OD values of $2.392 \pm 0.074$, $2.487 \pm 0.100$ and $2.592 \pm 0.139$, respectively, the proliferation of HUVECs in the SHPT group decreased significantly $(\mathrm{P} \leq 0.001$; Fig. 4). At $5-20 \%$, SHPT serum inhibited the proliferation of HUVECs in a concentration-dependent manner $(\mathrm{P}<0.05)$. The OD values for the SHPT group (5, 10 and 20\%) were $1.934 \pm 0.088,1.570 \pm 0.160$ and $1.282 \pm 0.150$, respectively (5 vs. $10 \%$ SHPT group, $\mathrm{P}=0.004 ; 5$ vs. $20 \%$ SHPT group, $\mathrm{P}<0.001$ and 10 vs. $20 \%$ SHPT group, $\mathrm{P}=0.014$ ). 


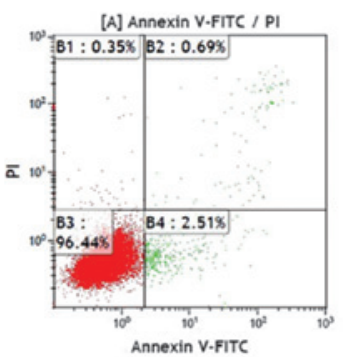

healthy volunteers serum group

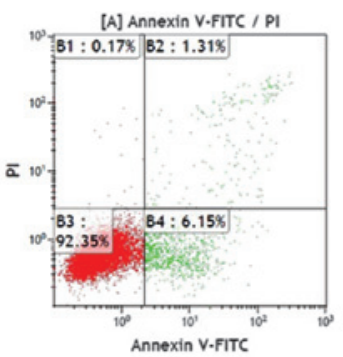

$100 \mathrm{ng} / \mathrm{ml} \mathrm{klotho}+$ SHPT group

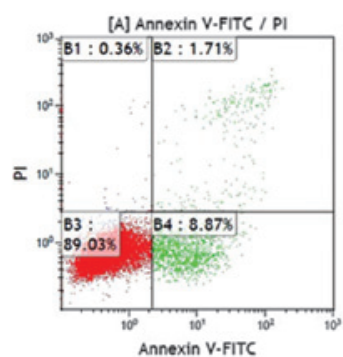

SHPT group

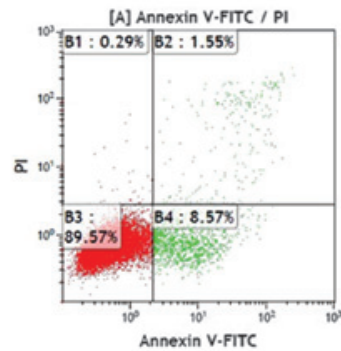

$50 \mathrm{ng} / \mathrm{ml} \mathrm{klotho}+\mathrm{SHPT}+\mathrm{PD}$ group

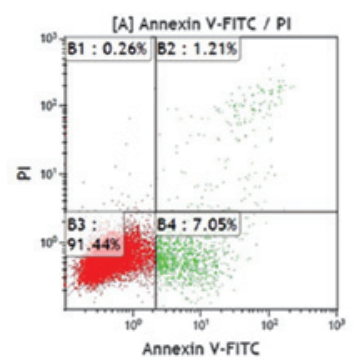

$50 \mathrm{ng} / \mathrm{ml}$ klotho + SHPT group

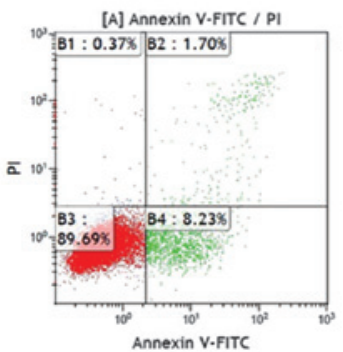

$100 \mathrm{ng} / \mathrm{ml}$ klotho + SHPT + PD group

Figure 8. Intervention of different concentrations of Klotho on the apoptosis of human umbilical vein endothelial cells incubated with $10 \%$ SHPT serum for 24 h. The experiments were repeated three times. PD: PD98059 (ERK1/2 inhibitor); SHPT, secondary hyperparathyroidism.

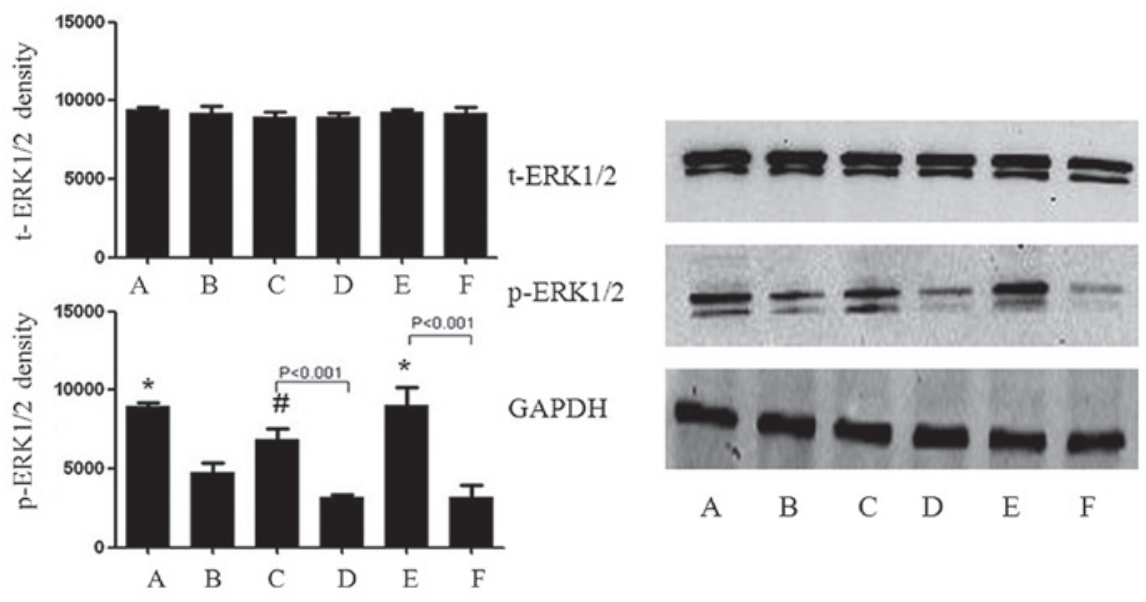

Figure 9. Intervention of different concentrations of Klotho with or without PD98059 (ERK1/2 inhibitor) on the expression of t-ERK1/2 and p-ERK1/2 of the human umbilical vein endothelial cells incubated with $10 \%$ SHPT serum for $24 \mathrm{~h}$. A, $10 \%$ healthy volunteers serum group; B, $10 \%$ SHPT group; C, 50 ng/ml Klotho +1 0\% SHPT serum group; D, 50 ng/ml Klotho + 10\% SHPT serum + PD98059 (ERK1/2 inhibitor) group; E, 100 ng/ml Klotho + 10\% SHPT serum group; F, $100 \mathrm{ng} / \mathrm{ml}$ Klotho $+10 \%$ SHPT serum + PD98059 group. ${ }^{*} \mathrm{P}<0.001$, vs. $10 \%$ SHPT group; ${ }^{*} \mathrm{P}=0.003$, vs. $10 \%$ SHPT group. The experiments were repeated three times. SHPT, secondary hyperparathyroidism.

SHPT serum inhibits the proliferation of HUVECs in a time-dependent manner. Compared with the healthy control group, with OD values at 6,12 and $24 \mathrm{~h}$ of $2.146 \pm 0.027$, $2.373 \pm 0.081$ and $2.608 \pm 0.047$, respectively, the OD values in the SHPT group decreased significantly $(1.767 \pm 0.062$, $1.599 \pm 0.018$ and $1.353 \pm 0.026$ at 6,12 and $24 \mathrm{~h}$, respectively; $6 \mathrm{~h}$ group vs. $12 \mathrm{~h}$ group, $\mathrm{P}=0.001 ; 6 \mathrm{~h}$ group vs. $24 \mathrm{~h}$ group, $\mathrm{P}<0.001 ; 12$ h group vs. 24 h group, $\mathrm{P}<0.001$; Fig. 5).

Klotho alleviates the inhibitory effect of SHPT serum on the proliferation of HUVECs in a concentration-dependent manner. Compared with the SHPT group (OD=1.598 \pm 0.078$)$, the proliferation of HUVECs was increased in the SHPT + Klotho (50 or $100 \mathrm{ng} / \mathrm{ml})$ group $(\mathrm{OD}=1.869 \pm 0.118$ and $2.021 \pm 0.123$, respectively; SHPT group vs. $50 \mathrm{ng} / \mathrm{ml}$ Klotho + SHPT group, $\mathrm{P}=0.01$ and SHPT group vs. $100 \mathrm{ng} / \mathrm{ml}$ Klotho + SHPT group, $\mathrm{P}=0.001$; Fig. 6). However, there was no statistically significant difference between the $25 \mathrm{ng} / \mathrm{ml}$ Klotho + SHPT group $(\mathrm{OD}=1.645 \pm 0.114)$ and the SHPT group $(\mathrm{P}=0.596)$.

The ERK1/2 inhibitor PD98059 abolishes the alleviating effect of Klotho on the inhibitory effect of SHPT serum on the proliferation of HUVECs. Compared with the healthy control group $(\mathrm{OD}=2.305 \pm 0.255)$, the proliferation of HUVECs in the SHPT group decreased significantly $(\mathrm{OD}=1.707 \pm 0.113$; $\mathrm{P}<0.001$; Fig. 7). The proliferation was partly restored when 


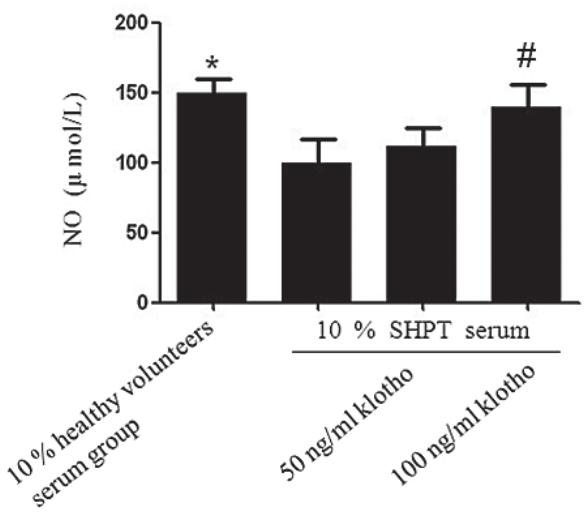

Figure 10. Intervention of different concentrations of Klotho on the production of NO of the human umbilical vein endothelial cells incubated with $10 \%$ SHPT serum for $24 \mathrm{~h} .{ }^{*} \mathrm{P}=0.03$ vs. $10 \%$ SHPT group; ${ }^{*} \mathrm{P}=0.039$, vs. $10 \%$ SHPT group. The experiments were repeated three times. SHPT, secondary hyperparathyroidism; NO, nitroc oxide.

50 or $100 \mathrm{ng} / \mathrm{ml}$ Klotho was added into the $10 \%$ SHPT serum, with OD values of $1.991 \pm 0.121(50 \mathrm{ng} / \mathrm{ml}$ Klotho; $\mathrm{P}=0.043)$ and $2.117 \pm 0.136(100 \mathrm{ng} / \mathrm{ml}$ Klotho; $\mathrm{P}=0.007)$. However, this effect was blocked by PD98059. When PD98059 was added to the 50 or $100 \mathrm{ng} / \mathrm{ml}$ Klotho group, the OD value decreased to $1.656 \pm 0.129$ or $1.681 \pm 0.117(50 \mathrm{ng} / \mathrm{ml}$ Klotho group vs. $50 \mathrm{ng} / \mathrm{ml}$ Klotho + PD98059, P=0.021; $100 \mathrm{ng} / \mathrm{ml}$ Klotho vs. $100 \mathrm{ng} / \mathrm{ml}$ Klotho + PD98059, P=0.005; Fig. 7).

Klotho inhibits apoptosis of HUVECs induced by SHPT serum. Compared with the healthy control group, SHPT serum induced apoptosis of HUVECs. The apoptotic rates of the SHPT group and healthy control group were $8.53 \pm 0.81$ and $3.21 \pm 0.59 \%$, respectively, and this difference was statistically significant $(\mathrm{P}<0.001)$. Of note, the apoptotic rate was reduced when 50 or $100 \mathrm{ng} / \mathrm{ml}$ Klotho was added to the $10 \%$ SHPT serum, resulting in apoptotic rates of $6.14 \pm 0.86$ and $5.86 \pm 0.98 \%$, respectively $(50 \mathrm{ng} / \mathrm{ml} \mathrm{Klotho}+$ SHPT group vs. SHPT group, $\mathrm{P}=0.001 ; 100 \mathrm{ng} / \mathrm{ml}$ Klotho $+\mathrm{SHPT}$ group vs. SHPT group, $\mathrm{P}=0.001)$. In addition, the anti-apoptotic effect was blocked by the ERK1/2 inhibitor PD98059. In the $50 \mathrm{ng} / \mathrm{ml}$ Klotho + SHPT + PD98059 group, the apoptotic rate was $8.12 \pm 1.03 \%$, which was significantly different compared with that in the $50 \mathrm{ng} / \mathrm{ml}$ Klotho + SHPT group (P=0.006). In the $100 \mathrm{ng} / \mathrm{ml}$ Klotho + SHPT + PD98059 group, the apoptotic rate was $7.87 \pm 0.65 \%$, which was significantly different compared with that in the $100 \mathrm{ng} / \mathrm{ml}$ Klotho + SHPT group ( $\mathrm{P}=0.005$; Fig. 8).

Klotho inhibits the SHPT serum-stimulated repression of $p$-ERK1/2 in HUVECs. Compared with the SHPT group, the expression of $\mathrm{t}-\mathrm{ERK} 1 / 2$ was not affected by Klotho; however, p-ERK1/2 was markedly upregulated. This effect of Klotho was blocked by PD98059 (Fig. 9).

Klotho abrogates the SHPT serum-mediated inhibition of NO production in HUVECs. Compared with the healthy control group, the production of NO in the SHPT group decreased significantly for the incubation period of $24 \mathrm{~h}$ (99.94 $\pm 16.28 \mu \mathrm{mol} / 1$ vs. $149.50 \pm 10.16 \mu \mathrm{mol} / 1 ; \mathrm{P}=0.03$; Fig. 10).
However, NO production increased in the SHPT + Klotho group $(50 \mathrm{ng} / \mathrm{ml} \mathrm{Klotho,} 111.35 \pm 13.33 \mu \mathrm{mol} / 1$ and $100 \mathrm{ng} / \mathrm{ml}$ Klotho, $139.78 \pm 15.89 \mu \mathrm{mol} / \mathrm{l})$. There was a statistically signifcant difference between the $100 \mathrm{ng} / \mathrm{ml}$ Klotho + SHPT group and the SHPT group ( $\mathrm{P}=0.039$; Fig. 10).

\section{Discussion}

Linder et al (13) proposed the concept of 'accelerated atherosclerosis' in 1974 and hypothesized that accelerated atherosclerosis is a major risk factor affecting the long-term survival of hemodialysis patients. The particular pathophysiological state in uremia patients may result in endothelial cell dysfunction $(2,14)$. Compared with non-SHPT uremia, in uremic patients with SHPT, despite of urea, creatinine, indole, phenolic compounds, guanidines, amines and other toxins (15), their PTH concentrations are several times higher than normal levels. Serum PTH levels $>70 \mathrm{pg} / \mathrm{ml}$ may become independent risk factors for CVD in CKD stage 3-4 patients $(14,16)$. Excessive PTH is another risk factor for increasing vascular endothelial damage and for these patients, their symptoms of CVD are more serious. Slowing the development of CVD in patients with SHPT is a priority in treating SHPT. The prevention and treatment of accelerated atherosclerosis, which may reduce the morbidity and mortality of cardiovascular events may improve the outcome of patients with SHPT. Atherosclerosis is a state in which a series of molecular and cellular changes are involved, resulting from endothelial injury. Vascular endothelial injury and dysfunction is a critical link to atherosclerosis formation. Regarding the risk factors for atherosclerosis in patients with SHPT, traditional risk factors, including high cholesterol, smoking status, diabetes and hypertension are important. In addition, other non-traditional factors, including a variety of uremic toxins, immune dysfunction, calcium and phosphorus metabolism, high PTH, hyperlipidemia, oxidative stress, micro-inflammation, hyperhomocysteinemia, advanced glycation end products and advanced oxidation protein products may all induce endothelial cell dysfunction and are involved in promoting the formation of atherosclerosis $(17,18)$. Endothelial cells are the basic structural and functional unit of the vascular endothelium, which has an important role in barrier function and regulating the exchange of substances inside and outside the vessel. The repair of injured endothelial cells predominantly relies on the movement and proliferation of adjacent normal cells (19). The growth and proliferation of endothelial cells and endothelial repair are closely associated with the incidence of atherosclerosis (20). The present study demonstrated that, compared with healthy human serum, the proliferation of HUVECs was inhibited by the serum of SHPT patients and CKD-5 patients without SHPT. Of note, the inhibition by SHPT serum was greater than that by serum from patients with CDK-5 withouth SHPT, suggesting that the SHPT state can accelerate the occurrence of atherosclerosis more markedly.

In recent years, the Klotho gene and protein, which have a key role in aging and aging-associated diseases aroused growing interest. Human Klotho exists in two forms (21-23), as membrane-bound proteins and a secreted form. Klotho protein may act as a hormonal factor to protect against endothelial cell injury induced by oxidative stress $(24,25)$. It has been demon- 
strated that the expression of Klotho was negatively correlated with the development of atherosclerosis in the uremia model of apolipoprotein E knockout mice induced by unilateral renal cortical electrical cautery plus contralateral kidney resection (26). Decreased levels of Klotho may be involved in the process of atherosclerosis in uremia (26). Of note, researchers have proposed in recent years that the uremia itself is an uncontrolled process of aging. Anti-aging therapy may be a novel approach to prevent uremia (27). The present study found that Klotho protein can partially restore proliferation and inhibit apoptosis of HUVECs treated with SHPT serum, suggesting that atherosclerosis induced by SHPT serum may be partly antagonized by Klotho protein.

As has been established, NO is one of the most important vascular relaxing factors derived from endothelial cells. As a cellular messenger molecule, in addition to vasodilation, NO also has a variety of effects on the blood vessels, including the maintenance of vascular elasticity, inhibition of platelet aggregation induced by adenosine diphosphate, effective platelet disaggregation, and inhibition of lymphocyte, granulocyte and monocyte adhesion to the vascular endothelium (28-30). These effects of NO make it an important protective factor against the formation of atherosclerosis. The alterations in the production of NO from endothelial cells are likely to affect the normal protective mechanisms of blood vessels. The present study found that NO production was inhibited by SHPT serum and enhanced by Klotho, suggesting that Klotho protein may protect endothelial cells by inducing the synthesis of NO.

The mitogen-activated protein kinase (MAPK) signal transduction pathway is an important signal transduction system in vivo (31). The ERK1/2 signal transduction pathway belongs to the MAPK family, which has an important role in cell growth, the cell cycle, cell stress, apoptosis and other physiological and pathological processes $(32,33)$. It can regulate cell proliferation, differentiation and cytoskeletal rearrangement as well as a number of other biological activities. p-ERK1/2 is an important activated form in the ERK1/2 signaling pathway, which is involved in the expression of genes, migration, differentiation and proliferation in cells (34-37). The present study identified that Klotho protein may partially restore the proliferation and vitality of HUVECs and inhibit their apoptosis when treated with SHPT serum, accompanied by $\mathrm{p}$-ERK1/2 upregulation. In addition, the effects of Klotho may be inhibited by PD98059, a specific ERK1/2 inhibitor, suggesting that the ERK1/2 signaling pathway is involved in the vascular protective effect of the Klotho protein.

These experimental results revealed that Klotho protein had a protective effect on endothelial cells and is a potential therapeutic factor for the prevention of atherosclerosis with SHPT. Based on these findings, further study of the Klotho protein is warranted.

\section{Acknowledgements}

The present study was supported in part by research grants from the National Science and Technology Pillar Program during the Twelfth Five-year Plan Period (grant no. 2011BAI 10B00), the Medical Scientific Research Foundation of Jiangsu Province (grant no. Z201002) and the Priority Academic Program Development(PAPD) of Jiangsu Higher Education Institutions.

\section{References}

1. Foley RN, Parfrey PS and Sarnak MJ: Clinical epidemiology of cardiovascular disease in chronic renal disease. Am J Kidney Dis 32 (5 Suppl 3): S122-S129, 1998.

2. Jourde-chiche N, Dou L, Cerini C, et al: Vascular incompetence in dialysis patients-protein-bound uremic toxins and endothelial dysfunction. Semin Dial 24: 327-337, 2011.

3. Van Ballegooijen AJ, Reinders I, Visser M, et al: Parathyroid hormone and cardiovascular disease events: A systematic review and meta-analysis of prospective studies. Am Heart J 165: 655-664, 2013.

4. Kuro-o M, Matsumura Y, Aizawa H, et al: Mutation of the mouse klotho gene leads to a syndrome resembling aging. Nature 3909: 45-51, 1997.

5. Kamemori M, Ohyama Y, Kurabayashi M, et al: Expression of klotho protein in the inner ear. Hear Res 171: 103-110, 2002.

6. Nagai T, Yamada K, Kim HC, et al: Cognition impairment in the genetic model of aging klotho gene mutant mice: a role of oxidative stress. FASEB J 17: 50-52, 2003.

7. Anamizu Y, kawaguchi H, Seichi A, et al: Klotho insufficiency causes decrease of ribosomal RNA gene transcription activity, cytoplasmic RNA and rough ER in the spinal anterior horn cells. Acta Neuropathol 109: 457-466, 2005.

8. Hu MC, Shi M, Zhang J, et al: Klotho deficiency causes vascular calcification in chronic kidney disease. J Am Soc Nephrol 22: 124-136, 2011.

9. Rakugi H, Matsukawa N, Ishikawa K, et al: Anti-oxidative effect of klotho on endothelial cells through cAMP activation. Endocrine 31: 82-87, 2007.

10. Carracedo J, Buendia P, Merino A, et al: klotho modulates the stress response in human senescent endothelial cells. Mech Ageing Dev 133: 647-654, 2012.

11. Yang K, Nie L, Huang Y, et al: Ameliration of uremic toxin indoxyl sulfate-induced endothelial cell dysfunction by klotho protein. Toxicol Lett 215: 77-83, 2012.

12. Komaba H and Fukagawa M: FGF23-parathyroid interaction: implications in chronic kidney disease. Kidney Int 77: 292-298, 2010.

13. Linder A, Charra B and Sherrard DJ: Accelerated atherosclerosis in prolonged maintenance hemodialysis. N Eng J Med 290: 697-701, 1974.

14. Eberhardt RT, Forgione MA, Cap A, et al: Endothelial dysfunc dysfunction in a murine model of mild hyperhomocyst(e)inemia. J Clin Invest 106: 483-491, 2000.

15. Raff AC, Meyer TW and Hostetter TH: New insights into uremic toxicity. Curr Opin Nephrol Hypertens 17: 560-565, 2008.

16. Bhuriva R, Li S, Chen SC, et al: Plasma parathyroid hormone level and prevalent cardiovascular disease in CKD stages 3 and 4: an analysis from the Kidney Early Evaluation Program. Am J Kidney Dis 5 Suppl 4: 3-10, 2009.

17. de Groot K, Bahlmann FH, Sowa J, et al: Uremia causes endothelial progenitor cell deficiency. Kidney Int 66: 641-646, 2004.

18. Choi JH, Kim KL, Huh W, et al: Decreased number and impaired angiogenic function of endothelial progenitor cells in patients with chronic renal failure. Arterioscler Thromb Vasc Biol 24: 1246-1252, 2004.

19. Carmeliet P, Moons L, Stassen JM, et al: Vascular wound healing and neointima formation induced by perivascular electric injury in mice. Am J Patho 150: 761-776, 1997.

20. Goligorsky MS, Yasuda K and Ratliff B: Dysfunctional endothelial progenitor cells in chronic kidney disease. J Am Soc Nephrol 21: 911-919, 2010.

21. Matsumura Y, Aizawa H, Nakamura T, et al: Identification of the human klotho gene and its two transcripts encoding membrance and secreted klotho protein. Biochem Biophys Res Commun 242: 626-630, 1998

22. Shiraki-lida T, Aizawa H, Matsumura Y, et al: Structure of the mouse klotho gene and its two transcripts encoding membrane and secreted protein. FEBS Lett 424: 6-10,1998.

23. Tohyma O, Imura A, Iwano A, et al: Klotho is novel beta-glucuronidase capable of hydrolyzing steroid beta-glucuronidase. J Biol Chem 279: 9777-9784, 2004.

24. Kachiwala SJ, Harris SE, Wright AF, et al: Genetic influences on oxidative stress and their association with normal cognitive aging. Neurosci Lett 386: 116-120, 2005.

25. Yamamoto M, Clark JD, Pastor JV, et al: Regulation of oxidative stress by the anti-aging hormone klotho. J Biol Chem 280: 38029-38034,2005. 
26. Jie YU, Deng M, Zhao J, et al: Decreased expression of klotho gene in uremic atherosclerosis in apolipoprotein E-deficient mice. Biochem Biophys Res Commun 391: 261-266, 2010.

27. Kooman JP, Broers NJ Uswat L, et al: Out of control: accelerated aging in uremia. Nephrol Dial Transplant 28: 48-54, 2013.

28. Zou MH, Shi C and Cohen RA: Oxidation of the zinc-thiolate complex and uncoupling of endothelial nitric oxide synthase by peroxynitrite. J Clin Invest 109: 817-826, 2002.

29. Moncada $S$ and Higgs EA. Nitric oxide and the vascular endothelium. Handb Exp Pharmacol 176 (Pt 1): 213-254, 2006.

30. Lubos E, Handy DE and Loscalzo J: Role of oxidative stress and nitric oxide in atherothrombosis. Front Biosci 13: 5323-5344, 2008.

31. Lawrence MC, Jivan A, Shao C, et al: The roles of MAPKs in disease. Cell Res 18: 436-442, 2008.

32. Cross TG, Scheel-ToellnerD, Henriquez NV, et al: Serine/threonine protein kinases and apoptosis. Exp Cell Res 256: 34-41, 2000.
33. Pearson G, Robinson F, Beers Gibson T, et al: Mitogenactivated protein (MAP) kinase pathways: regulation and physiological functions. Endocr Rev 22: 153-183, 2001.

34. Cobb MH: MAP kinase pathways: Prog Biophys Mol Biol 71: 479-500, 1999.

35. Xia Z, Dickens M, Raingeaud J, et al: Opposing effects of ERK and JNK-p38 MAP kinases on apoptosis. Science 270: 1326-1331, 1995

36. Steelman LS, Bertrand FE and McCubrey JA: The complexity of PTEN: mutation, marker and potential target for therapeutic intervention. Expert Opin Ther Targets 8: 537-550, 2004.

37. Steelman LS, Pohnert SC, Shelton JG, et al: JAK/STAT, Raf/MEK/ERK, PI3K/Akt and BCR-ABL in cell cycle progression and leukemogenesis. Leukemia 18: 189-218, 2004. 